\title{
Thai Learners' English Pronunciation Competence: Lesson Learned from Word Stress Assignment
}

\author{
Attapol Khamkhien \\ Department of Liberal Arts, Faculty of Liberal Arts and Science, Kasetsart University, Nakhon Pathom 73140 Thailand \\ Email: tanky_attapol@yahoo.com
}

\begin{abstract}
English has been a lingua franca in various domains of communication such as international business, academic conferences, diplomacy, science and technology. As a result, the demands for English skills in all aspects are crucial in response to the importance of English and the impact of globalization. Despite the constant efforts in developing English education in Thailand, a number of studies have shown that the achievement of Thai learners was unsatisfactory. Given the role of English as an international language which is used in almost domain of communication, amongst several factors hindering the success of English language learning, English pronunciation of the Thai learners should be focused. This study has two principle objectives: 1) to examine Thai learners' knowledge with regard to word stress assignment; and 2) to determine possible factors affecting the Thai learners' pronunciation competence. To achieve these objectives, 90 Thai learners of English participated in this study. The test consisting of two parts: personal information profile, and 40 selected words systematically taken from two textbooks, was employed to identify these participants' pronunciation competence. The results showed that most of the participants' English pronunciation was somewhat limited. Gender was identified to be the most significant factor contributing to the participants' test scores, while faculty and years of studying English were not. In light of the results suggested by the three variables, pedagogical suggestions were offered to help improve teaching and learning English pronunciation in general, and in focusing on the importance of teaching word stress in particular.
\end{abstract}

Index Terms —word stress assignment, Thai learners, English pronunciation

\section{INTRODUCTION}

Along with economic globalization, English has increasingly become the medium of communication around the world both in local and global contexts. The realization of importance of English highlights the necessity of every country to have its people become better equipped with English performance. Inevitably, this necessity is also applicable to Thailand. In response to the demands for English skills, the Thai government has made constant efforts to improve Thai learners' English performance throughout the history of English language teaching in Thailand (Kanoksilapatham, 2007) in order to improve Thai learners' competence in English, enabling them to obtain job opportunities, promotions or career advancement.

With the rise in the number of English users, English language teaching professionals has increased worldwide. The importance of English has also sparked a growing interest in the teaching of English as a foreign language (EFL). In Thailand, to meet the demands of global economics and to cope with the growing local and national demands for English skills, new initiatives have been launched in all aspects of the Thai educational system, including curriculum, materials, facilities, and professional development for teachers. However, a number of studies (e.g., Pongsiriwet, 2002; Wiriyachitra, 2001) reported that the four skills of listening, speaking, reading, and writing are far from satisfactory. The results of these studies were repeatedly substantiated by Bolton's (2008) study which reported that Thai learners' English performance was somewhat limited, compared to that of other ASEAN country members.

To improve Thai learners' English proficiency, among all the four macro language skills, speaking seems intuitively the most important because speaking includes all other skills of knowing that language (Ur, 1996). Given the role of speaking skills in learning a foreign language, teaching and learning English speaking in Thailand is somewhat limited for a number of reasons. First, for Thai students, English speaking or oral communication in English is deemed to be difficult since English is not their native language (Khamkhien, 2010). Second, most of Thai learners need their English to sound as native-like as possible which is a prestige norm of spoken English even though English is widely used in the region of South East Asia, creating a great diversity of English e.g., Malaysian English, Singaporean English, etc. This scenario seems to limit their choice of their exposure to English. Next, since English in Thailand is a foreign language, the exposure of English to authentic language input of learners of English in Thailand is limited. Lastly, another dimension which should be taken into account lies into English pronunciation of Thai teachers of English (Kanoksilapatham, 2007). These serious problems are exclusively important, leading to a large volume of studies 
focusing on speaking ability of Thai learners (e.g., Jarusan 1997; Kanoksilapatham, 1992; Nimphaibule, 1996; Serttikul, 2005; Siriwisut, 1994).

Since pronunciation is a global construct which consists of segmental (e.g., consonant and vowels) and suprasegmental (e.g., stress, intonation, rhythm, rate, volume), over the past decade, a number of studies have variedly investigated the area of speaking skills, including speaking assessment (e.g., Chen, 2001; Li, 2003; Wang 2003), phonology language acquisition (e.g., Altmann, 2006; Waylan et al., 2006), problems of teaching and learning speaking skills (e.g., Goodwin, 2001; Lazaraton, 2001). Amongst these studies focusing on speaking skills, pronunciation is receiving more attention in many EFL classrooms since it is recognized that students should primarily acquire as a fundamental skill because it can effect accuracy and comprehension (Celce-Murcia et al., 2000; Derwing et al., 2006; Hahn, 2004). Although research studies on speaking skills and pronunciation are common within English as a second and foreign language, the research of this line with Thai learners seems to be marginalized. Specifically, the area of pronunciation produced by Thai learners of English studying in the field of sciences seems to be relatively less explored. In light of the shortage of this line of research, despite the importance for successful communication, this study aimed to explore pronunciation competence of Thai learners of English studying in the field of sciences by using a stress identification task. The roles of three factors: gender, faculty and years of studying English were also determined.

\section{LITERATURE REVIEW}

This section provides a description of factors which contribute to students' pronunciation competence. Subsequently, previous studies concerning English pronunciation competence of Thai students are presented.

\section{A. Factors Contributing to Students' Pronunciation}

Although some researchers believe that all learners have the same capacity to learn a second or foreign language because they have learned their first language, a number of EFL teachers have difficulties in improving the students' pronunciation problems. As a result, in the past, several researchers have put great efforts, asserted and suggested many factors affecting students' pronunciation (e.g., Brown, 1994; Celce-Murcia et al., 2000; Gillette, 1994; Kenworthy, 1987). In this regard, these previous studies have been repeatedly substantiated that factors such as native language, age, exposure, innate phonetic ability, identity and language ego, and motivation and concern for good pronunciation ability, appeared to have an influence on teaching and learning pronunciation.

Native language

According to Avery and Ehrlich (1987), learners of a language have different ways to speak the target language. The way they speak the target language is sometimes slightly different and sometimes highly different than the native speakers' do. Kenworthy (1987) also stated that the native language is the most influential factor in accounting for students' pronunciation especially foreign accents. That is, if the students are familiar with the sound system of their native language, they will be able to effectively diagnose their own difficulties. Kenworthy suggested that many first and second language carryovers can be overcome through a focused awareness and effort on the learners' part. In this sense, as asserted by Senel (2006), it should be noteworthy that interference or negative transfer from the first language is likely to cause errors in aspiration, intonation, rhythm, and melody in the target language. To illustrate, this problem can occur when the rules for combining the sounds in forms of syllables are different in two languages.

Age

Age plays a vital role in learning or improving pronunciation abilities. As can be seen, if learners can pronounce a second language with a native-like accent, they must have probably started to learn it during their childhood since these learners start their second language learning process in target language speaking people environment (Senel, 2006). An intriguing research study conducted by Brown (1992) investigating the age factor on learning pronunciation using a traditional listen-and-repeat exercise indicated that minimal pairs in the context of the sentences, conversation and role playing, adult learners were probably able to learn second language phonology as well as children did. A recent study which has stirred the interest in the age factor affecting English pronunciation abilities is Collier's study (2003). The study revealed that the older students were faster and more efficient that younger ones in the early states of language learning. In this regard, older students and adolescents developed their second language skills continuously, but adults would diminish after the first year. However, the study did not propose any evidence for a simple and straightforward link between age and ability in pronunciation of a new language.

Experience in studying English

Lacking of opportunity to practice English pronunciation is another prominent problem to advancing in English pronunciation. Several studies compared the pronunciation accuracy of people living in English-speaking countries and those who did not, revealing the difficulty with pronunciation of learners who did not live in an English speaking country in mastering English pronunciation. For instance, Siriwisut (1994) and Serttikul (2005) indicated that language experience had an effect on pronunciation ability. In their studies, language experience meant the opportunities to use English language in daily lives. The studies suggested that students with poor pronunciation, who were regarded as less experienced, had more language transfer problem than the students with good pronunciation. For this reason, the students with good pronunciation would improve better than the poor ones. Their findings were witnessed by Haymes (2000) and Senel (2006) pointing out that learners living in an English-speaking country or community where English is 
the second language would have many opportunities to listen to and to use the target language. Also, the success in learning and teaching English depended on students' ability and exposure. Teaching a conversation or a dialogue was, therefore, not enough to help students improve speaking skills. Likewise, Brown (1992) stated that the students could pronounce well if they spent time on pronunciation with full attention and interest. In short, students could simply improve the development of pronunciation competence if they were motivated and had a strong will to expose to the target language.

\section{Phonetic ability}

According to Brown (1992), phonetic ability is sometimes called phonetic coding ability. It is a common view that some people have a better listening skill for a foreign language than others. Therefore, they are able to discriminate between the two sounds more accurately than the others and ale to imitate sounds better. Although students may have had exposure to a foreign language as children and attuned to phonetic discrimination, some studies (e.g., Kanoksilapatham, 1992) have suggested that some elements of learning are a matter of awareness of the different sounds. Also, learners' pronunciation ability can be improved by putting efforts and concentration on those sounds.

Attitude and identity

Another interesting factor influencing on acquiring and improving pronunciation of the target language is one's attitude towards speakers of the target language and the extent to which the language ego identified with those speakers. As pointed out by Brown (1992), students with a positive attitude towards the people who spoke the target language were likely to learn pronunciation more successfully. They were not afraid of the second identity that may have been emerging within them. Moreover, a similar caution was sounded by Celce-Murcia et al. (2000) who noted that attitude towards the target language, culture, personal identity issues, and motivation for learning could all support or impede pronunciation skills development. Apart from these factors, as astutely asserted by Senel (2006), in general, shy or introvert students would not prefer to participate in classroom activities, leading to the lack of any opportunities to make practices and to make full use of phonological activities.

\section{Motivation and concern for good pronunciation}

The learners' motivation can be seen the strongest factor contributing to the success or failure of learning a second or foreign language. That is, it is a driving force encouraging a learner to pursue a course of action, initiating the learning, and finally sustaining the learning process (Dörnyei, 2001). Basically, if the learners' motivation is high, then they will be willing to improve their abilities by themselves. On the other hand, if they do not see the value or pay attention to their pronunciation, they may not be motivated to do well.

The previous research studies mentioned above confirm the roles of native language, age, experience in studying English, phonetic ability, attitude and identity, and motivation and concern for good pronunciation in studying a language as important factors affecting learners' pronunciation. However, there exists a rigorous on-going debate between scholars and researchers from different context of language learning and teaching, propounding various versions of implications and cautions in teaching pronunciation. This calls for more studies focusing more specifically on a specific context to support the main tenets of progressive language pedagogy.

\section{B. Previous Studies on Pronunciation}

A number of researchers focusing on English pronunciation problems of Thai learners have created their own experiment or tests. For example, an insightful study focusing on Thai learners' pronunciation of English was conducted by Kanoksilapatham (1992). The findings of her study indicated that Thai learners of English had difficulty with English pronunciation, especially in pronouncing four-syllable English words. Specifically, among four types of the words tested: nouns, verbs, adjective, and adverbs, verbs were found to be least-well pronounced, whereas the nouns with an -ity ending were most correctly pronounced. The findings were interesting, demonstrating that that incorrect placement of word stress was evident; in certain words, final syllables seemed to be stressed rather than the first syllables.

Looking at the relationship between the perception and the production of English word stress by Thai learners, Jarusan (1997) found that the learner's English experience played a vital role in the perception and the production of English word stress. The study suggested that language learning experience and the exposure to the language could help the learners to learn a foreign language and have a constant of their language ability. However, the listening ability was individualistic as constant practice and continuous exposure to the language which will help the language learners develop their language ability in a long term aspect are needed.

English loan words are considered to be a problem for Thai speakers of English. Korsuwan (2001) studied the assimilation of English loan words by Thai speakers. It was found that the problem of pronunciation occurred from background knowledge and Thais' behavior to share the phonological both in Thai and English language. Most Thai speakers decided the accuracy by imitating the phonological pattern from hearing. Moreover, the study indicated that consonant sounds, vowel sounds and clusters were problematic for Thai learners especially the final cluster consonant such as /l/ and /ch/. In a nutshell, most Thai speakers substituted to pronounce the difficult sounds by adding their own rules to pronounce easily.

Although the preponderance of previous studies focused on Thai learners' pronunciation of English, and yield congruent results that Thai learners of English had difficulty with English pronunciation, certain criticism of limitations of such studies should be taken into account. First, different scholars and researchers have investigated learning 
strategies from different aspects and area of speaking skills, leading to somewhat different pedagogical implications. In addition, creating researchers' own tests and questionnaires to meet the establish objectives of previous studies lead to questions of the reliability and application of the analysis. Then, despite the enormous number of learning variables studies, many studies tend to focus on one factor to investigate in a study. Finally, in this light of this line of research, there is very little research focusing on Thai students' English pronunciation studying in the field of sciences. These reasons suggest a need for more studies in this research area.

\section{METHODOLOGY}

\section{A. Objectives of the Study}

The current study aims to assess Thai learners' English pronunciation competence. In this study, English pronunciation competence refers to the knowledge to perform pronunciation through the word stress assignment. Specifically, the study has two main objectives: (1) to assess Thai learners' knowledge with regard to word stress assignment, and (2) to determine possible factors contributing to these learners' pronunciation competence. More specifically, this study attempted to answer the following questions:

1. What is the level of Thai learners' English pronunciation competence?

2. What is the relationship between three factors: gender, faculty and experiences in studying English, and their knowledge with regard to word stress assignment?

\section{B. Participants}

The participants were Thai learners of English $(N=90)$, studying in the field of sciences, from the Faculty of Liberal Arts and Science, Engineering, and Veterinary Medicine, Kasetsart University, Thailand. All of them, at the time of study, were second year students, and were randomly selected to participate in this study. These participants were ideal for this study for several reasons. First, they were a homogeneous group of students studying in mixed-ability class. Second, Thai was their mother tongue, and they had no formal exposure to the spoken variety of the language other than that in the classroom. Finally, they were studying English courses, which contribute positively to the study, allowing certain generalizations to be made.

\section{Instruments}

The instrument used in the current study consists of two parts. Part one of the test is the background questionnaire eliciting personal information of the participants. The questions asked in this part represent the following variables: 1) gender, 2) faculty and major, and 3) years of studying English. As for the last factor (years of studying English), it should be noted that, in Thailand, students learn English as a compulsory subject from Grade 1 onwards. Since the participants in the current study were studying in the university level, studying English for at least 12 years was taken into account.

Part two of the test is regarded as the main instrument in this study. This part comprises a list of selected words to test the participants' word stress competence. To select the words used in this part, first, a list of 60 words was complied from two main sources, namely Introductory Chemistry (Tro, 2008), and Chemistry: An introduction to general, organic, and biological chemistry (Timberlake, 1996). Since all of the participants were studying in the field of sciences, it was expected that these students would be familiar with the words selected from these books which were used as a main stream in the instruction. Then, in order to assure the reliability of the words listed, all of the words to be used were cross checked, referring to Academic Press Dictionary of Science and Technology (Christopher, 1992) which was prescribed to technical terms used in the scientific field. To assure that the words tested represent the proportion of the words used in the scientific field, related to the contents they were studying, this word list was also checked by three experts who are scientists and instructors in a subject matter.

To assure that the data obtained from the participants can be generalized, the list of 60 words was used in a pilot study with 10 students. The results of the pilot study suggested that the participants had a difficulty understanding some words on the test, and thus 20 words were excluded from the list. As a result, in the current study, a list of 40 multisyllabic words was selected and used as the test of the word stress assignment competence of the participants. Since one of the objectives of the current study focuses on English pronunciation and as far as the syllable numbers are concerned, these 40 words are divided into four groups: two-syllable words (e.g., process, data), three-syllable words (e.g., chemistry, energy), four-syllable words (e.g., automatic, environment) and five-syllable words (e.g., metabolism, antioxidant) with 10 words each. All of these words selected were arranged in the ascending order based on their number of syllables. That is, the test begins with a group of two-syllable words and ends with five-syllable words.

\section{Data Collection}

The test administration took place in the second semester of academic year 2009. The test was distributed to the participants into three classes on the last day of the semester. In this regard, the author administered the test. Before the test administration, the participants were informed that the first part of the test required the participants to complete their personal information, whereas the second part asked them to identify the stressed syllable in each word by marking an X that corresponds to the syllable they perceived to place a stress on. In order to assess the real these participants' 
competence, they were also informed that the test results would be kept confidentially, and the results of the test would be beneficial for the research study and improving teaching English.

\section{E. Data Analysis}

After the test administration, the data obtained from part one eliciting personal information of the participants were coded and divided into groups for statistical analysis. As for the data gained from the task of word stress assignment, the test was scored manually and dichotomously by the author. The correct answer was assigned with 1 , and 0 to an incorrect one. All data were analyzed by the SPSS program, showing descriptive statistics. In order to determine the effect of the three variables: gender, faculty and years of studying English, separate $t$-tests and separate ANOVAs were performed.

\section{RESULTS}

The analysis and the descriptive statistics of the test scores from the word stress assignment task showed that, in general, the mean score is 16.84 . The highest score is 26 , while the lowest score is 9 , and the $S D$ value is 3.35 . In this regard, it was found that Thai learners had a difficulty with pronouncing five-syllable words most, and two-syllable words least. Based on these results, given that the words covered in the test were taken from the textbooks they must study in the classroom, it is clear that the relatively low mean score of 16.84 demonstrates that their performance on word stress assignment test is far from satisfactory.

As for the personal data elicited by the first part of the test, the number and the percentage of the participants are presented in Table 1. Further, the results on the investigation of the relationship between test scores and the variables were individually reported as follows.

TABLE1:

PERSONAL DATA OF THE PARTICIPANTS

\begin{tabular}{ccc}
\hline & No. of participants & Percent \\
\hline Gender & 52 & 57.78 \\
Male & 38 & 42.22 \\
Female & 38 & 42.22 \\
Faculty & 30 & 33.33 \\
Arts and Science & 24.45 \\
Engineering & 22 & 84.45 \\
Veterinary Medicine & 76 & 15.55 \\
\hline English Learning Experience & 14 & 24.5 \\
\hline 1-12 years & & \\
\hline
\end{tabular}

\section{A. Test Results by Gender}

To examine how gender of the participants affects their English pronunciation competence, the data elicited by the first part of test were analyzed. A number of intriguing points were found. The results of their pronunciation competence by gender are presented in Table 2.

TABLE2:

TEST RESULTS BY GENDER

\begin{tabular}{|c|c|c|c|c|}
\hline Gender & Minimum & Maximum & Mean & S.D. \\
\hline Male & 12.00 & 25.00 & 15.73 & 3.06 \\
\hline Female & 9.00 & 26.00 & 18.37 & 3.14 \\
\hline Total & 9.00 & 26.00 & 16.84 & 3.35 \\
\hline
\end{tabular}

Of 90 participants, as shown in Table 1 , most of them are male $(\mathrm{M}=57.78$ or 52 students), and 38 participants are female $(M=42.22)$. As for the test scores, as Table 2 illustrates, the female participants in this study could perform slightly better than the male counterparts in the identification task. The result of the analysis indicates that the mean score of 18.37 is for female participants, and 15.73 for the male ones. Therefore, there is a small difference between the female group and the male one. Although the descriptive statistics does not reveal any major different between the task scores between male and female students, the ANOVA reveals a statistically significant difference $(\mathrm{F}=15.90, \mathrm{p}=0.00)$. This finding shows that the scores of the identification task revealed main significant effect for gender.

B. Test Scores by Faculty 
The second variable explored in this study is the participants' faculty. In this case, the data from the participants were classified based on their faculty. The following table demonstrates the comparison of the test scores by faculty.

TABLE3:

TEST RESULTS BY FACULTY

\begin{tabular}{ccccc}
\hline Faculty & Minimum & Maximum & Mean & S.D. \\
\hline Arts and Science & 9.00 & 25.00 & 16.11 & 3.43 \\
Engineering & & & & \\
Veterinary Medicine & 13.00 & 26.00 & 17.47 & 3.06 \\
\hline Total & 10.00 & 24.00 & 17.85 & 3.48 \\
\hline
\end{tabular}

Focusing on the faculty of the participants, the results demonstrated that the participants studying, in the time of study, in the faculty of Veterinary Medicine (mean score of 17.85), performed slightly better than those studying in the faculty of Engineering (mean score of 17.47), and those from the faculty of Liberal Arts and Science (mean score of 16.11). However, the lowest score of those from the faculty of Engineering is 13, followed by those from the faculty of Veterinary Medicine and Liberal Arts and Science (10 and 9, respectively). ANOVA was performed on the mean scores and yielded non-significant contrasts $(\mathrm{F}=1.65, \mathrm{p}=0.20)$, demonstrating that the participants with different in their faculty did not differ in their word stress assignment scores.

\section{Experiences in Studying English}

In order to successfully determine and get a clearer picture of the roles of years in studying English on the scores of word stress assignment task, the data from the first part of the test were coded into two groups of students, 1-12 years and more than 12 years, particularly. The difference in the test scores by years of studying English is shown in the following table.

TABLE4:

TEST RESULTS BY EXPERIENCES IN STUDYING ENGLISH

\begin{tabular}{ccccc}
\hline Years of Studying English & Minimum & Maximum & Mean & S.D. \\
\hline 1-12 years & 9.00 & 26.00 & 17.00 & 3.51 \\
More than 12 years & 13.00 & 20.00 & 16.00 & 2.22 \\
\hline Total & 9.00 & 26.00 & 16.84 \\
\hline
\end{tabular}

The results of the analysis revealed that, incredibly, the participants who have learned English for 1 to 12 years performed slightly better than those studying English for more than 12 years, with the mean scores of the former of 17.00, and 16.00 for the latter. Again, ANOVA was performed on their mean scores, and revealed that there was no statistically significant different $(\mathrm{F}=1.06, \mathrm{p}=0.31)$. This indicates that the test scores of the two student groups were not significantly different in their word stress assignment.

\section{DISCUSSION}

This study aimed at assessing English pronunciation of Thai learners of English. The participants in this study were studying in the field of sciences. The results of this study, generally, showed that these Thai learners' English pronunciation competence was rather limited. The results of the current study can shed light onto some practical suggestions and implications on teaching and learning pronunciation.

The results obtained from this study suggest that Thai learners of English need to be sharpened their English knowledge and paid more attention to the importance of pronunciation features. This does not mean that not only will English teachers be a decent model of pronunciation for their students, but teachers responsible for other subject matters should be a resource person in the classroom as well. Specifically, gender was identified as one of the contributing factors to the scores of the identification task, while faculty and years of studying English were not. Basically, the teachers should be aware of the individual difference which might have and effect on the students' pronunciation competence.

Although English language teaching and learning in Thailand mostly focuses on the four macro language skills, pronunciation, as mentioned earlier, is relatively neglected. The results of this study have highlighted the role of pronunciation not only in language classes in general but in specific courses, in the field sciences in particular. If the students were not able to perform or pronounce English words correctly, they might have difficulties when listening, speaking, reading and writing English textbooks, leading to serious problems in response to the needs of international demands. Given that there was no significant difference in the test scores by years of studying English of the participants, it can be said that, even though some of the students had more experience in studying English that their 
counterparts, the status of English in Thailand is recognized as a foreign language. Most of the students will have no chance or opportunity to use the target language in a real environment. Therefore, teachers and learners should be aware of the necessity of being exposed to the target language by making full use of video shows, films, radio or TV programs, computer assisted language teaching programs in teaching and learning English to help boost their pronunciation competence.

To facilitate the acquisition of stress pattern, explicit instruction might be needed. Classroom instructor of English can help language learners enhance their sensitivity to stress pattern in a number of ways. For instance, teaching methods and class activities provided should make the students aware of their pronunciation problems and help them correct themselves. In this regard, authentic materials and recorders can be employed in the language classroom. Moreover, teachers should encourage recording of whatever is being studied at home. English teachers themselves should initially be aware of the expertise expected of teachers. That is, they should possess knowledge of instruction, knowledge of context, and expertise related to the subject matter, word stress assignment because the teachers' pronunciation is the major input that the learners are exposed to.

Moreover, the results of this study calls for an interest of classroom English teachers and involved parties to sharpen their sensitivity and to pay more attention to pronunciation features. This is because the awareness to enhance pronunciation competence will be beneficial to teachers in general and to students in particular. Therefore, as suggested by Kanoksilapatham (1992), to improve the practices in the subject matter, educational administrators should take some initiatives to improve the teacher preparation program to introduce and adequate skills to cope with the expected role of a resource person. Teachers themselves should be provided with the opportunities to acquire practical skills and knowledge needed to function as an effective teacher. Meanwhile, these teachers and the students should be fostered to understand their own experience when stresses are misplaced in words. Finally, these teachers should be cautioned that pronunciation should not be overlooked since it had an impact on teachers' performance and subsequently their students' performance.

\section{CONCLUSION}

This study explored Thai learners' English pronunciation competence. The results in general revealed that most of the Thai learners did not possess satisfactory competence in English pronunciation. Clearly seen from the analysis, it was found that, based on the scores of 90 Thai participants, their word stress placement was somewhat unsatisfactory. To further determine which of the three variables are significantly different, ANOVAs were performed, and the statistical results revealed significant difference in gender, but not in faculty and years of studying English. Therefore, it can be said that gender is a significant predictor of Thai learners' performance in the identification task.

\section{LIMITATIONS OF THIS STUDY}

The results of this study should be interpreted carefully for several reasons. First, given the limited number of the students, the findings of this study remain inconclusive and call for subsequent studies analyzing a larger group of participants. Next, as discussed in the literature, it is possible that pronunciation competence of the learners might be influenced by other pertinent variables e.g. age, field of study, phonetic ability, etc. In addition, there is a limitation in selecting words covered in the test from two textbooks used to assess the learners' word stress scores, future research, thus, should be systematically supplemented with other sources which might provide and support the ways to assess pronunciation competence of the learners. Moreover, further investigation should investigate the relationship between the learner's English language pronunciation competence and actual performance.

\section{REFERENCES}

[1] Altmann, H. (2006). The Perception and Production of Second Language Stress: A cross linguistic experimental study. Unpublished Doctoral Dissertation, University of Delaware.

[2] Avery, P. \& Ehrlich, S. (1987). Preliminary considerations in the teaching of pronunciation. London: TESL Center.

[3] Bolton, K. (2008). English in Asia, Asian Englishes, and the issue of proficiency. English Today, 24(2), 3-12.

[4] Brown, A. (1992). Approaches to pronunciation teaching. London: Macmillan.

[5] Brown, H. (1994). Teaching by principles: An interactive approach to language pedagogy. New Jersey: Englewood Cliffs.

[6] Celce-Murcia, M., Brinton, D., \& Goodwin, J. (2000). Teaching pronunciation: A reference for teachers of English to speakers of other languages. Cambridge: Cambridge University Press.

[7] Chen, T.M. (2001). A study of the relationship between communication strategies and English proficiency evaluation by SLOPE. Unpublished Master's thesis, Providence University, Taiwan, R.O.C.

[8] Christopher, M. (1992). Academic Press Dictionary of Science and Technology. San Diego Academic Press.

[9] Collier, V. (2003). The effect of age on acquisition of a second language for school. Retrieved on June 10, 2010 from http://www.ncela.gwu.edu/pubs/directions/04.htm.

[10] Derwing, T.M., Thomson, R.I., \& Munro, M.J. (2006). English pronunciation and fluency development in Mandarin and Slavic speakers. System, 34, 183-193.

[11] Dörnyei, Z. (2001). Teaching and researching motivation. Harlow: Longman. 
[12] Gillette, G. (1994). On speaking terms: Practical guide to pronunciation for ABLE/ESL teachers. Euclid, OH: Northeast ABLE Resource Center.

[13] Goodwin, J. (2001). Teaching pronunciation. In M. Celce-Murcia (Ed). Teaching English as a second or foreign language. Boston: Heinle and Heinle.

[14] Hahn, M.K. (2002). The persistence of learned primary phrase stress patterns among learners of English. Unpublished Doctoral Dissertation, University of Illinois at Urbana-Champagne.

[15] Haymes, J. (2000). The development of interactive oral proficiency in the classroom. Retrieved on June 10, 2010 from: http://www.developingteachers.com/articles_tchtraining/orprof1_jake.htm.

[16] Jarusan, P. (1997). Perception and production of English word stress of first year students at Rangsit University. Unpublished Master's thesis, Chulalongkorn University.

[17] Kanoksilapatham, B. (1992). An analysis of English pronunciation of third year English major students. Silpakorn University: Nakhon Pathom.

[18] Kanoksilapatham, B. (2007). Navigating pathways to success in ELT. Journal of English Studies, 3, 6-25.

[19] Kenworthy, J. (1987). Teaching English pronunciation. New York: Longman.

[20] Khamkhien, A. (2010). Teaching English speaking skills and English speaking tests in the Thai context: A reflection from Thai perspective. English Language Teaching, 3(1), 184-190.

[21] Korsuwan, N. (2001). A study of English loan words in standard Thai: A preliminary phonological analysis of their assimilation. Unpublished Master's thesis, Ramkhamhang University.

[22] Lazaraton, A. (2001). Teaching oral skills. In M. Celce-Murcia (Ed). Teaching English as a second or foreign language. Boston: Heinle and Heinle.

[23] Li, M.C. (2003). Factors affecting adult EFL learners' speaking performance: Planning and proficiency. Unpublished Master's thesis, the National Taiwan Normal University, Taiwan, R.O.C.

[24] Nimphaibule, S. (1996). Variation of Thai air hostesses' pronunciation of the final consonants (ts, dZ, $\Sigma$ ) in English words. Unpublished Master's thesis, Chulalongkorn University.

[25] Pongsiriwet, C. (2002). Relationships among grammatical accuracy, discourse features, and the quality of second language writing: The case of Thai EFL learners. Unpublished doctoral dissertation, West Virginia University.

[26] Senel, M. (2006). Suggestions for beautifying the pronunciation of EFL learners in Turkey. Journal of Language and Linguistic Studies, 2(1), 111-125.

[27] Serttikul, S. (2005). The production of final /-1/ in English words in Thai and English contexts by Thai speakers with different English-language experience. Unpublished Master's thesis, Chulalongkorn University.

[28] Siriwisut. (1994). The variation of final /1/ in English words in Thai by Thai speakers with different English-language experience. Unpublished Master's thesis, Chulalongkorn University.

[29] Timberlake, K.C. (1996). Chemistry: An introduction to general, organic, and biological chemistry. New York: HarperCollins.

[30] Tro, N.J. (2008). Introductory chemistry. NJ: Prentice Hall.

[31] Ur, P. (1996). A course in language teaching: Practice and theory. Cambridge: Cambridge University Press.

[32] Wang, Y.C. (2003). Communication-orientation in Freshman English curriculum: A new response. Paper presented at the 12 Conference on English Teaching and Learning in the Public of China (pp. 588-598). Taipei: Crane Publishing Co., Ltd.

[33] Waylan, R., Guion, S.G. \& Landfair, D. (2006). Native Thai speakers' acquisition of English word stress patterns. Journal of Psycholinguist Research, 35(3), 285-304.

[34] Wiriyachitra, A. (2001). A Thai university English scenario in the coming decade. Thai TESOL Newsletter, 14(1), 4-7.

Attapol Khamkhien is a lecturer at the Faculty of Liberal Arts and Science, Kasetsart University, Thailand. He received an M.A. in English as an International Language (EIL) from Chulalongkorn University, Thailand. His main interests include language learning styles and strategies, English as an international language, vocabulary development for EFL learners and academic writing. 